$U D C 78.071 .2$

DOI $10.33287 / 222022$

Furdui Yulia,

PhD in Arts, teacher

of the chair "History and Theory of Music» M. Glinka Dnipropetrovsk Academy of Music

tel. (067) 810 - 46 - 99

e-mail: audiojoysmile@gmail.com http://orcid.org/0000-0002-0354-5706

Yehorova Olena,

Magister of the chair «Folk instruments» M. Glinka Dnipropetrovsk Academy of Music

tel. (099) 256 - 02 - 69

e-mail: egorova5.elena@gmail.com

\title{
GENRE CHARACTERISTICS \\ OF ROMANTIC FANTASY FOR THE GUITAR ON A BORROWED THEME BY F. TARREGA
}

The purpose of this article is to identify the individual-style features and genre characteristics of romantic fantasy for the academic professional guitar. The methods of the research are based by investigator on the application of a comprehensive approach, namely: evolutionary and historical methods - in the disclosure of the processes of formation and subsequent evolution of the genre under study; analytical - in the study of different genre literature, concerning the chosen problem and others. The scientific novelty lies in the fact that fantasies for F. Tarrega's guitar is analyzed by researcher for the first time. On their example, the individualstyle features of the fantasy genre are revealed by scholar. Conclusions. In the course of the work, the genre characteristics of F. Tarrega's romantic fantasy were analyzed, and it was discovered that virtuosity comes to the forefront as a mandatory quality of fantasy, which was associated with the emergence of virtuosos of composers and performers Napoleon Costa and Francisco Tarrega. Thanks to them, the guitar falls a focus of attention of famous virtuosos who study its chamber and orchestral capabilities. Fantasies for the guitar are improved in form and thematism, using as exclusively original thematism, and borrowed. In the era of romanticism, fantasies on a borrowed topic get the most development, a prerequisite for 
which was the growth of a virtuoso style of performance, which undoubtedly led to revolutionary achievements in the field of expressive means. One of the main features of guitar fantasies on a borrowed topic was the superiority not of composing, but of performing means of expression: agogics, dynamics, intonation and others. Fantasies for the guitar are extremely virtuosic and require considerable performing skills. However, virtuoso techniques are only of a subordinate nature, and borrowed themes become only an impulse for creating a new artistic integrity. From the point of view of the actual musical structure, such works are characterized by a combination of the form of fantasy with the variational principle of material development.

The key words: instrumental fantasy, romantic fantasy, genre, fantasy, guitar.

Фурдуй Юлія Володимирівна, кандидат мистецтвознавства, викладач кафедри «Історія та теорія музики» Дніпропетровської академії музики ім. М. Глінки

Сгорова Олена Леонідівна, магістрант кафедри «Народні інструменти» Дніпропетровської академії музики ім. М. Глінки

Жанрові характеристики романтичної фантазії для гітари на запозичену тему Ф. Тарреги

Мета статті полягає у виявленні індивідуально-стильових особливостей і жанрових характеристик романтичної фантазії для гітари на запозичену тему. Методи дослідження грунтуються на застосуванні комплексного підходу, а саме - еволюційного та історичного методів - у розкритті процесів формування й подальшої еволюції досліджуваного жанру; аналітичного - в опрацюванні різножанрової літератури, стосовно обраної проблеми та ін. Наукова новизна полягає в тому, що вперше аналізуються фантазії для гітари Ф. Тарреги. На цьому прикладі розкриваються індивідуальностильові особливості жанру фантазії. Висновки. У ході роботи були проаналізовані жанрові характеристики романтичної фантазії Ф. Тарреги, та виявлено, що віртуозність виходить на перший план як обов'язкова якість фантазії, що було пов'язано з появою віртуозів композиторів-виконавців Наполеона Коста й Франциско Тарреги. Дякуючи цим музикантам, гітара потрапляє у центр уваги прославлених віртуозів, які вивчають іiі камерні й оркестрові можливості. Фантазії для гітари вдосконалюються за формою й тематизмом, використовуючи як виключно оригінальний тематизм, 
так i запозичений. В добу романтизму найбільшого розвитку отримують фантазії на запозичену тему, передумовою чого стало зростання віртуозного стилю виконавства, що безумовно призвело до революційних здобутків у сфері засобів художньої виразності. Однією із основних особливостей гітарних фантазій на запозичену тему стала перевага не композиторських, а виконавських засобів виразності: агогіки, динаміки, інтонування тощо. Фантазії для гітари $\epsilon$ надзвичайно віртуозними i потребують значної виконавської майстерності. Проте, віртуозні прийоми носять лише підпорядкований характер, а запозичені теми стають лише імпульсом для створення нової художньої цілісності. 3 погляду власне музичної структури для таких творів характерне поєднання форми фантазії 3 варіаційним принципом розвитку матеріалу.

Ключові слова: інструментальна фантазія, романтична фантазія, жанр, фантазія, гітара.

Фурдуй Юлия Владимировна, кандидат искусствоведения, преподаватель кафедры «История и теория музыки» Днепропетровской академии музыки им. М. Глинки

Егорова Елена Леонидовна, магистрант кафедры «Народные инструменты» Днепропетровской академии музыки им. М. Глинки

Жанровые характеристики романтической фантазии для гитары на заимствованную тему Ф. Тарреги

Цель статьи заключается в выявлении индивидуально-стилевых особенностей и жанровых характеристик романтической фантазии для гитары. Методы исследования основаны на применении комплексного подхода, а именно: эволюционного и исторического методов - в раскрытии процессов формирования и дальнейшей эволюции исследуемого жанра, аналитического - в разработке разножанровой литературы, относящейся выбранной проблемы и др. Научная новизна статьи заключается в том, что впервые анализируются фантазии для гитары Ф. Тарреги. На их примере раскрываются индивидуально-стилевые особенности жанра фантазии. Выводы. В ходе работы были проанализированы жанровые характеристики романтической фантазии Ф. Тарреги, и было обнаружено, что виртуозность выходит на первый план как обязательное качество фантазии, что связывается с появлением виртуозов композиторов-исполнителей Наполеона Коста и Франциско Тарреги. Благодаря им гитара попадает в центр внимания 
прославленных виртуозов, которые изучают её камерные и оркестровые возможности. Фантазии для гитары совершенствуются по форме и тематизму, используя как исключительно оригинальный тематизм, так и заимствованный. В эпоху романтизма наибольшего развития получают фантазии на заимствованную тему, предпосылкой чего стал рост виртуозного стиля исполнения, что безусловно привело к революционным достижениям в сфере средств художественной выразительности. Одной из основных особенностей гитарных фантазий на заимствованную тему стало превосходство не композиторских, а исполнительских средств выразительности: агогики, динамики, интонирования и т.д. Фантазии для гитары чрезвычайно виртуозны и требуют значительного исполнительского мастерства. Однако, виртуозные приёмы носят лишь подчиненный характер, а заимствованные темы становятся лишь импульсом для создания новой художественной целостности. С точки зрения музыкальной структуры для таких произведений характерно сочетание формы фантазии с вариационным принципом развития материала.

Ключевые слова: инструментальная фантазия, романтическая фантазия, жанр, фантазия, гитара.

Statement of the problem. The fantasy genre plays a significant role in the academic-concert guitar repertoire and plays an important role in the work of many composers, influencing the development and transformation of a number of other genres. However, genre and stylistic features of fantasy until the nineteenth century were in the process of change. The reasons for this are probably not only the large variety of types, branches of the genre, but also that freedom has always been one of its main features. Researchers differently place emphasis on the characteristics of the fantasy genre.

Relevance of research. The instrumental fantasy genre has evolved over the centuries. The formation of the fantasy genre was directly related to the significant flowering of lute art in the sixteenth century. At every historical stage, in accordance with the development of musical culture, peculiarities of stylistics, technique of presentation of material, fantasy also changed. At different times, it closely touched genres that were common in one era or another, enriching and filling with new qualities.

The greatest development of fantasy genre was in Romanticism. It attracts romantic composers, first of all, because it allows to express the 
freedom of creative imagination as full as it possible. In romantic times, fantasy plays a significant role in the concert repertoire of performers, creating an opportunity to demonstrate the artist's virtuosity and skill.

Most of the research attention is paid to the fantasy for piano. However, the signs of fantasy as a particular genre system in the guitar art are still not sufficiently understood.

F. Tarrega's creativity was formed on the border of two centuries and two musical epochs - classical and romantic. The influence on his art of the traditions of his predecessors was also reflected in the genre of fantasy for the guitar.

Literature review. Detailed studies of the fantasy genre, as such, are devoted to scientific works by I. Palazchenko [5], K. Shtryfanova [6], Y. Cherniavskaia [3], O. Shchogolieva [4], which consider the genesis of the genre; to study genre features of fantasy for the lute; fantasies for piano in R. Schumann's creations; to disclose the specifics of romantic instrumental fantasy in the compositions by celebrated F. Schubert and R. Schuman.

The purpose of this article is to identify the individual-style features and genre characteristics of fantasy on borrowed themes for the guitar on the analysis of the works of F. Tarrega.

The object of this item is the fantasy genre for guitar in the era of Romanticism. The subject of the study - the individual-style features of fantasies on borrowed themes by F. Tarrega.

Presenting main material. Instrumental fantasy is rooted in first half of the sixteenth century and has more than four hundred years of history. Over the course of its existence, the genre has evolved, changing depending on being in the context of particular musical cultures and styles. At every historical stage, in accordance with the development of musical culture, features of new stylistics and methods of composition, fantasy also changed.

The fantasy genre for guitar as such declares itself in Spanish music in mature baroque (in the creations of Francisco Bartolomeo Sanz). Genre independence is gained through the manifestation of the main content property - the conscious improvisational freedom of the composition, the internal desire to overcome the rhythmic, mood, emotional monotony. Some eclectic fantasy stylistics testify to:

- a transitional state of musical thinking from a polyphonic, church-based system to the major-minor system; 
- from the theme of polyphonic-contrapuntal type to the new homophonic expanded, expressive vocal-instrumental type.

In Classicism defined by strict genre canonicality and rational norms, the fantasy genre develops slowly, keeping the formed meaningful features. The classic fantasy stores:

- combination of contrasting, strikingly different elements;

- freedom from text and improvisation.

The peculiarity of constructing a composite fantasy plan is:

- gradual sharpening of contrasts;

- increasing the intensity of figurative comparisons in the development of the whole.

The concert and symphonic possibilities of the guitar are revealed. L. Bokkerini introduces the guitar to the quintet, writes the first symphony with a party of obligatory guitar.

Thanks to these factors, classical fantasies for the guitar are refined in form and subject, enriched with new, more sophisticated techniques acquired in experiments to introduce into the practice of new technique, using both purely original thematic and borrowed.

The nineteenth century and the era of Romanticism culminated in the development of fantasy and its appeal to composers, which is conditioned not only by an «orientation to the violation of the canon». The word «fantasy» together with «imagination» and «feeling» becomes a key concept of the era. Romantic fantasy unfolds to the level of principle that unites many genres: medley, processing, impromptu, capricious, musical moment, poem and many others. It penetrates into unrelated genres of sonata, symphonies, concerts, integrates with free and mixed forms. Fantasy acquires a permanent genre independence, without leaving aside the general stylistic context of the romantic development of genres such as bagatelle, dances, variations, characteristic plays, potpourri, rondo, divertissements and waltzes.

Widespread fantasies on popular opera themes. Synthetic genres of «sonata-fantasy» are formed, which combine the features of sonata form with freedom of presentation, and fantasies - paraphrases written on popular themes from operas. The obvious influence on the development of fantasy for the guitar is a fantasy in the works of F. Liszt, who acquires symphonic features, becomes not so much a translation of the vocal theme for the piano, but rather a composition with serious thematic transformations and dramatic conflict (for example, the fantasy «Don 
Juan» on theme of Mozart). Accordingly, the fantasy of the guitar deepens the features of the software.

Virtuosity comes to the fore as a compulsory quality of fantasy, which was associated with the emergence of virtuoso composersperformers Ferdinando Carulli, Napoleon Cost, Francisco Tarrega.

Thanks to them, the guitar gets into the limelight of illustrious virtuosos exploring its chamber and orchestra capabilities. As a result of these factors, the fantasy of the guitar uses techniques borrowed from the practice of modern violinists and pianists, such as fast arpeggios, ascending and descending passages and etc.

It should be noted that the growth of virtuoso style of performance was realized due to fantasies on a borrowed theme during the Romantic period. Along with the borrowed topics, selected by contrast, the original theme is used. Brilliant passages of improvisational character were used as the connection between the themes.

Fantasies on popular topics are constructed in the type of contrastfolded form. Variation plays a significant role here. Guitar fantasies are extremely virtuosic and require considerable performing skills. However, virtuoso techniques are only subordinate in nature, and borrowed topics are only an impulse to create a new artistic integrity. From the point of view of the actual musical structure, such works are characterized by a combination of a form of fantasy and a variational principle of material development.

The structure of such compositions was as follows: introduction of improvisational character; variational development of one or more topics in which the dynamics of instrumental development play a major role; sometimes a contrasting slow part is introduced (even more rarely a fast dance section); an indispensable attribute is the fast virtuoso finale. The selection of topics is often based on the criterion of their popularity, the possibility of variational development of the topic being borrowed.

The analysis of romantic fantasy on opera themes by F. Tarrega as a bright example of this type was carried out. The pearl of F. Tarrega's work is a fantasy on the themes of the opera «La Traviata» by D. Verdi, which is the main component of the concert program of modern performers. The original interpretation of the Tarrego fantasy genre is manifested in the asymmetry of the Fantasy form on themes from the opera Traviata, which is reminiscent of the genre of variations, but has a freer, improvisational profile - introduction and five sections. The content of fantasy is determined by the thematic choice of not one, but several, contrasting 
emotional themes for fantasy. The three main lyric-dramatic elements that make up the musical dramaturgy of love drama, themes are taken as the basis. These are two orchestral prelude themes that characterize Violetta.

The first, which is in the opera Verdi, sadly, almost inconsistently sounds in the violin of the division, symbolizing the sick, on the verge of death, the main lyrical hero. The second, temperamental, waltz, expressive, symbolizes the true love of Violetta. The third is the theme of the declaration of love of Alfred.

Significant originality in the interpretation of opera themes is added by the individual rather sophisticated and new performing guitar techniques (artificial flagpoles, trills, glissando, arpeggios, legato, forshlags, mordents, ascending and descending guitar legato, arpeggios, arpeggiatsion, raspegetiato, rasas processing vocal material, texturally enriching it and creating quasi-instrumental re-singing of the motifs and orchestral effects of their development.

The composer seeks to preserve the original material of the opera, its authorial authenticity, and at the same time, original, unique by unique stylistic means (rhythmic and tempo-metric changes in the middle or point of the «golden section» of sections (piu mosso, acell, ad libitumctum), updates the genre of fantasy guitar basics, determining the influence on the chosen operatic themes of the instrumental factor, the selection of virtuoso guitars, which creates different expressiveness and a new imaginative content of the theme in fantasy.

The romantic fantasy for the guitar has undoubtedly become the source of the development of various genres of guitar art of the twentieth century. Therefore, the question of the relationship between romantic and contemporary genres for the guitar, based on fantasy and improvisation, needs further scientific study.

Conclusions. The work analyzes fantasy on operatic themes of F. Tarreg's Romanticism as a prime example of this type. Borrowed topics were selected on the principle of artistic contrast, but it should be noted that the original theme is used. The artistically professional performing links between the themes were virtuoso passages that are improvisational in nature.

However, romantic fantasy for the guitar has undoubtedly become a source of development of various genres of guitar art of the twentieth century. Therefore, the question of the relationship between romantic and contemporary genres for the guitar, based on fantasy and improvisation, needs further scientific study. 
Prospects for the study of the genre of romantic fantasy are relevant and necessary in the domestic musicological practice, as well as further deepening in the study, the identification of certain stylistic features of works of this genre.

\section{Список використаних джерел і літератури:}

1. Медушевский В. Фантазия в культуре и музыке. Музыка, Культура, Человек. Свердловск, 1991. С. 44-51.

2. Ляхина Т. О некоторых особенностях произведений на заимствованные темы в творчестве виртуозов ХІХ века. Вестник СпбГУКИ. 2014. № 1 (18). С. 133-137.

3. Чернявская Ю. Фантазийные сочинения Роберта Шумана: к истории и теории жанра фантазии : автореф. ... канд. искуствоведения: 17.00.02. Москва, 2017. 24 с.

4. Щеголева A. Романтическая инструментальная фантазия в творчестве Ф. Шуберта и Р. Шумана: пути становления жанра: автореф. ... канд. мистецтвознавства: 17.00.03. Одеса, 2011. 24 с.

5. Палажченко И. Инструментальная фантазия XVII - XVIII веков : автореф. ... канд. искуствоведения: 17.00.03. Москва, 1992. 24 с.

6. Штрифанова К. Фантазія для лютні XVI століття: становлення жанру : автореф. ... канд. мистецтвознавства : 17.00.03. Харків, 2007. 17 с.

\section{References:}

1. Medushevskij, V. (1991). Fantasy in culture and music. Muzyka, Kul'tura, Chelovek. Sverdlovsk [in Russian].

2. Ljahina, T. (2014). On some features of works on borrowed themes in the works of virtuosos of the $19^{\text {th }}$ century. Vestnik SpbGUKI, 1 (18), 133-137 [in Russian].

3. Chernjavskaja, Ju. (2017). Fantasy compositions by Robert Schumann: to the history and theory of the fantasy genre. Extended abstract of candidate's thesis. Moskov [in Russian].

4. Shhegholeva, A. (2011). Romantic instrumental fantasy in the works of F. Schubert and R. Schumann: ways of the genre formation. Extended abstract of candidate's thesis. Odesa [in Ukrainian].

5. Palazhchenko, I. (1992). Instrumental fantasy of the $17^{\text {th }}-18^{\text {th }}$ centuries. Extended abstract of candidate's thesis. Moskov [in Russian].

6. Shtryfanova, K. (2007). Fantasy for the lute of the $16^{\text {th }}$ century: the formation of the genre. Extended abstract of candidate's thesis. Kharkiv [in Ukrainian]. 